\title{
Low Permeability to Oxygen of a New Barrier Film Prevents Butyric Acid Bacteria Spore Formation in Farm Corn Silage
}

\author{
G. Borreani ${ }^{1}$ and E. Tabacco \\ Dipartimento di Agronomia, Selvicoltura e Gestione del Territorio, University of Torino, Grugliasco (Torino), Italy
}

\begin{abstract}
The outgrowth of Clostridium spore-forming bacteria causes late blowing in cheeses. Recently, the role of air diffusion during storage and feed-out and the role of aerobic deterioration has been shown to indirectly favor butyric acid bacteria (BAB) growth and to determine the presence of high concentrations of $\mathrm{BAB}$ spores in farm tank milk. A new oxygen barrier (OB) film was tested and compared with conventional polyethylene (ST). The objective was to verify whether the OB film could prevent $\mathrm{BAB}$ spore formation in whole-crop corn silage during storage on 2 commercial farms with different potential silage spoilage risks. Two bunkers (farms 1 and 2) were divided into 2 parts along the length so that half the feed-out face would be covered with ST film and the other half with OB film. Plastic net bags with freshly chopped corn were buried in the upper layer and in the central part (CORE) of the bunkers. The silos were opened in summer and fed out at different removal rates (19 vs. $33 \mathrm{~cm} / \mathrm{d})$. Herbage at ensiling, silage at unloading, and silage after air exposure (6 and $15 \mathrm{~d})$ were analyzed for $\mathrm{pH}$, nitrate, BAB spores, yeasts, and molds. The BAB spores in herbages at ensiling were $2.84 \log _{10}$ most probable number $(\mathrm{MPN}) / \mathrm{g}$, with no differences between treatments or farms. Nitrate was below the detection limit on farm 1 and exceeded $2,300 \mathrm{mg} / \mathrm{kg}$ of fresh matter on farm 2 . At unloading, the $\mathrm{BAB}$ spores in the $\mathrm{ST}$ silage on farm 1 were greater than $5 \log _{10} \mathrm{MPN} / \mathrm{g}$, whereas in the CORE and the OB silages, they were approximately $2 \log _{10} \mathrm{MPN} / \mathrm{g}$. The ST silage had the greatest $\mathrm{pH}$ (5.89), the greatest mold count $\left(5.07 \log _{10} \mathrm{cfu} / \mathrm{g}\right)$, and the greatest difference between silage temperature and ambient temperature $\left(\mathrm{dT}_{\text {section-ambient }}\right)$. On farm 2 , the $\mathrm{ST}$ silage had the greatest concentration of BAB spores (2.19 $\left.\log _{10} \mathrm{MPN} / \mathrm{g}\right)$, the greatest $\mathrm{pH}$ (4.05), and the least nitrate concentration compared with the CORE and the OB silages. Pooled data on $\mathrm{BAB}$ spores collected from aerobically deteriorated samples showed a positive relationship with $\mathrm{pH}$,
\end{abstract}

Received March 5, 2008.

Accepted June 22, 2008.

${ }^{1}$ Corresponding author: giorgio.borreani@unito.it mold count, and $\mathrm{dT}_{\text {section-ambient }}$ and a negative relationship with nitrate concentration. A high concentration of $\mathrm{BAB}$ spores (>5 log MPN/g) was associated with visible spoilage, high $\mathrm{pH}$ values $(>5.00)$, high mold counts (>5 log cfu/g), high $\mathrm{dT}_{\text {section-ambient, and nitrate below }}$ $1,000 \mathrm{mg} / \mathrm{kg}$ of fresh matter. We concluded that the use of a film with reduced oxygen permeability prevented the outgrowth of BAB spores during conservation and feed-out, and it could improve the microbiological quality of corn silage by eliminating the fractions of silage with high BAB spore concentrations.

Key words: butyric acid bacteria, corn silage, oxygen barrier film Silostop, aerobic deterioration

\section{INTRODUCTION}

The multiplication of spore-forming bacteria of the genus Clostridium causes off-flavors and excessive gas formation in either sweet cheeses such as Gruyère, Gouda, Edam, and Emmental or hard cheeses with long ripening times, such as Cheddar, Grana Padano, Beaufort, and Parmigiano Reggiano (Le Bourhis et al., 2005). This problem is frequently associated with Clostridium tyrobutyricum (Klijn et al., 1995). These bacteria, called butyric acid bacteria (BAB), are able to convert lactic acid into butyric acid, hydrogen, and carbon dioxide at a relatively low $\mathrm{pH}$. Recently, several commercial Grana Padano cheese makers have had problems with late blowing (from 15 to $35 \%$ of the total production) in some periods of the year, even though BAB spore concentration in the milk was lower than 2 $\log _{10}$ most probable number (MPN)/L (Colombari et al., 2001; G. Borreani and E. Tabacco; personal communication). Corn silages are known to be an important contamination source of BAB spores in raw milk through dung contamination during milking (Stadhousers and Spoelstra, 1990). The growth of clostridia in silage can take place during the acidification phase, the storage phase, and, as demonstrated by Jonsson (1991), on exposure of the material to air. The nitrate content of forages can play an important role in preventing BAB activity during fermentation when concentrations are greater than $1,000 \mathrm{mg} / \mathrm{kg}$ of fresh matter (FM; Spoelstra, 1983). 
Although clostridia are strict anaerobic microorganisms, some early studies have shown that BAB spore formation can be promoted by air penetration in silage (Ohyama et al., 1970; Kwella and Weissbach, 1991). Corn is often considered a good forage for ensiling because of its relatively high DM content, low buffering capacity, and usually adequate levels of fermentable sugars (McDonald et al., 1991). Corn silage cores usually contain less than $3 \log _{10}$ MPN/g of BAB spores (Colombari et al., 1999, 2001; Vissers et al., 2007). However, in the early 1980s French studies pointed out a large heterogeneity in clostridia spore counts in whole-crop corn silage stored in horizontal silos (Corrot, 1986). This author found low clostridia spore contamination levels (approximately $2 \log \mathrm{MPN} / \mathrm{g}$ ) in the core of the silos but high contamination levels ( $>5 \log _{10} \mathrm{MPN} / \mathrm{g}$ ) in the peripheral zones of the silos, which were more exposed to air. Recently, Vissers et al. $(2006,2007)$ emphasized the role of aerobic deterioration in corn silage at the farm level in relation to the presence of high concentrations of BAB spores in tank milk. Air diffusion during storage and feed-out indirectly favors BAB growth. When oxygen penetrates the silage, yeasts begin assimilating lactic acid, other fermentation products, and residual sugars, with an increase in temperature and $\mathrm{pH}$ (Pahlow et al., 2003). Thus, oxidation processes consume inhibitory substances and favor deterioration activity. As clearly described by Jonsson (1989), the growth of C. tyrobutyricum during oxygen penetration of silage can be explained by the maximal biological activity that takes place in the aerobic-anaerobic interface. The aerobic microorganisms consume oxygen close to the surface, and the aerobic-anaerobic zone moves toward the surface and anaerobiosis is restored in the deeper parts. Clostridium tyrobutyricum and other anaerobes can grow and multiply in this ecosystem in microniches with less inhibitory activity (Jonsson, 1989). When the $\mathrm{pH}$ rises, other less acid-tolerant clostridia, such as Clostridium sporogenes, can also grow (Cato et al., 1986).

Vissers et al. (2007) hypothesized that the outgrowth of $\mathrm{BAB}$ spores could probably be prevented by limiting the penetration of oxygen or inhibiting the detrimental effect of oxygen penetration during conservation and feed-out. A recent alternative sealing system (Silostop-125 m, IPM, Mondovì, Italy) has been developed that uses a new plastic formulation that is more impermeable to oxygen, which reduces spoilage and DM losses in the peripheral area of a silo (Borreani et al., 2007).

The aim of this work was to verify whether this new oxygen barrier film could prevent BAB spore formation in whole-crop corn bunker silos during conservation, during feed-out, and on air exposure. The tests were carried out on 2 commercial farms with different potential silage spoilage risks.

\section{MATERIALS AND METHODS}

\section{Crop and Ensiling}

Two trials were carried out on 2 commercial farms at Saluzzo (Cuneo; $44^{\circ} 40^{\prime}$ latitude, $7^{\circ} 32^{\prime}$ longitude, 325 $\mathrm{m}$ above sea level; farm 1) and at Frossasco (Torino; $44^{\circ} 75^{\prime}$ latitude, $7^{\circ} 23^{\prime}$ longitude, $290 \mathrm{~m}$ above sea level; farm 2) in 2005 and 2006 on corn silage in bunker silos to study the effect of 2 types of plastic sheeting used to seal the silos (standard polyethylene vs. a new concept oxygen barrier film, Silostop- $125 \mu \mathrm{m}$ ). The 2 sealing treatments were 1) a single sheet of $180-\mu \mathrm{m}$-thick (6 and $8 \mathrm{~m}$ wide for farm 1 and farm 2, respectively) black-on-white polyethylene (ST); 2) a single sheet of 125 - $\mu \mathrm{m}$-thick (6 and $8 \mathrm{~m}$ wide for farm 1 and farm 2 , respectively) black-on-white coextruded polyethylenepolyamide film with an enhanced oxygen barrier (OB). The silages sealed with ST and OB films were also compared with silages from the core of the bunker (CORE). The bunkers (filled with approximately 200 and 1,100 $\mathrm{t}$ of fresh silage for farm 1 and farm 2 , respectively) were divided into 2 parts along the length; half was covered with ST film, and half was covered with $\mathrm{OB}$ film to allow silage sampling at the same time for the 2 treatments. Approximately $2 \mathrm{~m}$ of the plastic sheeting was placed on the side wall and turned on the top surface of the silos at the end of filling, to have an overlap of approximately $40 \mathrm{~cm}$ of the 2 sheets in the middle of the silos. The 2 plastic sheets were held to the silage with tires and gravel bags near the side walls. When the silos were being filled, 8 plastic net bags ( 4 for each treatment) with well-mixed fresh material (approximately $7 \mathrm{~kg}$ of fresh weight per bag) were subsampled for preensiling analyses, weighed, and buried in the upper layer of the bunker in 2 sections $10 \mathrm{~m}$ apart. The bags were placed so as to be representative of the peripheral $40 \mathrm{~cm}$ of the stored silage. Four more bags were weighed and buried in the central part of each bunker (1.5 $\mathrm{m}$ from the top). The crop characteristics, bunker characteristics, and sampling procedures are described in detail in Borreani et al. (2007).

The silos were opened for summer consumption, and when the feed-out face reached a distance of 0.5 $\mathrm{m}$ from the bags, they were removed from the silos for analyses. Each bag was subsampled and analyzed for DM concentration (3 replicates) and chemical and microbiological parameters (2 replicates). The remaining silage was used for deterioration trials, which were performed in the laboratory by placing approximately $3 \mathrm{~kg}$ of silage from each bag of each treatment in duplicate 
$20-\mathrm{L}$ polystyrene boxes. These were allowed to deteriorate aerobically at room temperature. A single layer of aluminum cooking foil was placed over each container to prevent drying and contamination, but also to allow air penetration. The room temperature and the temperature from each silage were measured each hour by a data logger. Samples for $\mathrm{pH}$ and microbiological analyses were taken from each container after 6 and 15 d. Nitrate content and $\mathrm{pH}$ were monitored daily after the temperature increased by more than $2^{\circ} \mathrm{C}$ above the ambient temperature.

\section{Sample Preparation and Analyses}

The preensiled material, the silage at unloading, and the silage after air exposure were subsampled and analyzed for DM content, $\mathrm{pH}$, yeast and mold counts, $\mathrm{BAB}$ spore concentration, and nitrate content.

Dry matter content was determined by oven-drying at $80^{\circ} \mathrm{C}$ for $24 \mathrm{~h}$ and was corrected for volatile losses during drying. Herbage and silage extracts were prepared by adding $270 \mathrm{~mL}$ of deionized water to $30 \mathrm{~g}$ of sample and homogenizing for $4 \mathrm{~min}$ in a laboratory Stomacher blender (Seward Ltd., London, UK). The sample suspension was used for $\mathrm{pH}$ and nitrate measurements.

Nitrate content was determined by semiquantitative analysis, using Merckoquant test strips (Merck, Darmstadt, Germany) with a detection limit of $100 \mathrm{mg}$ of $\mathrm{NO}_{3}{ }^{-} / \mathrm{kg}$ (MacKown and Weik, 2004). Twenty randomly selected samples were also analyzed for nitrate concentration by ion chromatography. The extraction media were filtered through Whatman no. 1 paper, then through a $0.45-\mu \mathrm{m}$ syringe filter, and finally through a Dionex On Guard RP syringe filter (Dionex Corp., Sunnyvale, CA) before analysis with the flow-injection procedure. Nitrate in the solution was measured by using a Dionex-500 Ion Chromatograph (Dionex Corp.) equipped with a Dionex Ion Pac AS4A-SC analytical column and a Dionex Ion AG4A-SC guard column (Dionex Corp.) with an eluent of $1.8 \mathrm{~m} M$ carbonate and $1.7 \mathrm{~m} M$ bicarbonate. The resulting regression equation between the data obtained from ion chromatography $(\mathrm{mg} / \mathrm{kg})$ and the data obtained from the semiquantitative strips $(\mathrm{mg} / \mathrm{kg})$ was

$$
\begin{aligned}
& \text { Nitrate }(\text { strips })=0.997 \times \text { nitrate } \\
& \quad(\text { ion chromatography },
\end{aligned}
$$

with an adjusted $r^{2}$ of 0.948 and a root mean square error of 24. The data from the semiquantitative Merckoquant test strips were therefore used for the data discussion in this paper.
For the microbial counts, $30 \mathrm{~g}$ of sample was transferred into sterile homogenization bags, suspended $1: 10$ (wt/vol) in peptone physiological salt solution (PPS: $1 \mathrm{~g}$ of neutralized bacteriological peptone and $9 \mathrm{~g}$ of sodium chloride per liter), and homogenized for $4 \mathrm{~min}$ in a laboratory Stomacher blender (Seward Ltd.). Serial dilutions were prepared, and mold and yeast numbers were determined by using the pour plate technique with $40.0 \mathrm{~g} / \mathrm{L}$ of yeast extract glucose chloramphenicol agar (YGC agar, Difco, West Molesey, Surrey, UK) after incubation at $25^{\circ} \mathrm{C}$ for 3 and $5 \mathrm{~d}$ for yeast and mold, respectively. Mold and yeast colonyforming units were enumerated separately, based on their macromorphological features. The mean count of the duplicate subsamples was recorded for total yeasts and molds on plates that yielded 10 to 100 cfu per Petri dish.

The BAB spore concentration was determined by the MPN procedure. A serial 10-fold dilution was prepared in Ringer's solution (Oxoid Ltd., Hampshire, UK). Tubes from each dilution step containing $9 \mathrm{~mL}$ of sterilized reinforced Clostridium medium (RCM, Merck) supplemented with sodium lactate $(10 \mathrm{~mL} / \mathrm{L})$ and agar $(1.5 \mathrm{~g} / \mathrm{L})$ were each inoculated with $1 \mathrm{~mL}$ of diluted sample. The tubes were heated in a water bath for $10 \mathrm{~min}$ at $80^{\circ} \mathrm{C}$ to inactivate the vegetative cells and to trigger the germination of spores. The tubes were sealed with paraffin and incubated for $7 \mathrm{~d}$ at $37^{\circ} \mathrm{C}$. A tube scored positive if it exhibited abundant gas formation after incubation.

Temperature can be useful as a heating index related to the aerobic deterioration because increases in temperature are clearly linked to yeast activity and DM loss, and could help alert farmers to the onset of aerobic deterioration. The difference between silage temperature and ambient temperature was defined as $\mathrm{dT}_{\text {section-ambient }}$. During aerobic deterioration, hours with $t>35^{\circ} \mathrm{C}$ and hours with nitrate $<1,000 \mathrm{mg} / \mathrm{kg}$ of FM were also calculated to better describe the optimal temperature for $\mathrm{BAB}$ spore germination in the absence of inhibitory conditions (Spoelstra, 1983; Jonsson, 1989).

\section{Statistical Analysis}

All microbial counts were $\log _{10}$-transformed to obtain log-normal distributed data. To calculate averages, the values below the detection level (detection levels: 30 $\mathrm{BAB}$ spores/g, 10 yeast/g, and $10 \mathrm{mold} / \mathrm{g}$ ) were assigned a value corresponding to half the detection level (i.e., $15 \mathrm{BAB}$ spores/g, 5 yeast/g, and $5 \mathrm{mold} / \mathrm{g}$ ). The microbial counts, $\mathrm{pH}$, nitrate contents, and $\mathrm{dT}_{\text {section-ambient }}$ were analyzed via ANOVA by using the general linear model of the Statistical Package for the Social Sciences 
Table 1. Farm 1: Butyric acid bacteria (BAB) spores, molds, yeasts, $\mathrm{pH}$, and nitrate at ensiling of herbages from the core and from the peripheral areas, sealed with an oxygen barrier and standard polyethylene films

\begin{tabular}{|c|c|c|c|c|c|}
\hline Item & $\mathrm{CORE}^{1}$ & \multicolumn{2}{|c|}{ Plastic film ${ }^{2}$} & $\mathrm{SE}$ & $P$-value \\
\hline Molds, $\log _{10} \mathrm{cfu} / \mathrm{g}$ & 6.36 & 6.47 & 6.44 & 0.034 & 0.429 \\
\hline Yeasts, $\log _{10} \mathrm{cfu} / \mathrm{g}$ & 7.15 & 7.19 & 7.48 & 0.148 & 0.657 \\
\hline $\mathrm{pH}$ & 5.96 & 6.02 & 5.97 & 0.028 & 0.634 \\
\hline Nitrate concentration, $\mathrm{mg} / \mathrm{kg}$ of fresh matter & $<30$ & $<30$ & $<30$ & -3 & - \\
\hline
\end{tabular}

${ }^{1} \mathrm{CORE}=$ silage in the core of the bunker.

${ }^{2} \mathrm{OB}=$ silage under the oxygen barrier film; $\mathrm{ST}=$ silage under the polyethylene film.

${ }^{3}$ Statistical analysis not performed.

(version 11.5; SPSS Inc., Chicago, IL). Significant differences between means were considered significant at $P<0.05$. When the calculated values of $F$ were significant, the Duncan multiple range test $(P<0.05)$ was used to interpret any significant differences among the mean values. The number of hours with $t>35^{\circ} \mathrm{C}$ and the number of hours with nitrate $<1,000 \mathrm{mg} / \mathrm{kg}$ of FM were analyzed for their statistical significance via the Kruskal-Wallis nonparametric independent group comparison of SPSS and, because equal variances were not assumed, Tamhane's T2 post hoc test $(P<0.05)$ was applied to interpret any significant differences among the mean values.

Pooled data on BAB spore concentrations collected from aerobically deteriorated samples were regressed on $\mathrm{pH}$, mold count, nitrate concentration, and $\mathrm{dT}_{\text {section-ambient }}$ as the independent variables. Linear and quadratic regressions were compared by using the stepwise selection procedure of SPSS to select the best regression model at $P<0.05$. The best equation for each parameter was selected by using the coefficient of determination and root mean square error. All the reported determination coefficients $\left(\mathrm{r}^{2}\right)$ were adjusted for degrees of freedom.

\section{RESULTS}

Tables 1 and 2 list the BAB spore, yeast, and mold concentrations; $\mathrm{pH}$; and nitrate concentration in fresh corn before ensiling, from the CORE, and from the peripheral area of the bunker silos on farm 1 and farm 2, respectively. The BAB spore concentrations were 2.67 and $3.01 \log _{10} \mathrm{MPN} / \mathrm{g}$ for farm 1 and farm 2 , respectively. The yeast concentration ranged from 6.26 to $7.48 \log _{10}$ $\mathrm{cfu} / \mathrm{g}$, and the mold concentration ranged from 6.36 to $7.54 \log _{10} \mathrm{cfu} / \mathrm{g}$, with no differences between herbages from the CORE and the peripheral areas (OB and ST) of the 2 silos. The nitrate concentration was below the detection limit on farm 1 , whereas it exceeded 2,300 $\mathrm{mg} / \mathrm{kg}$ of FM on farm 2.

Tables 3 and 4 show the BAB spore, yeast, and mold concentrations; $\mathrm{pH}$; nitrate concentration; and $\mathrm{dT}_{\text {section-ambient }}$ in silage from the 2 bunkers at unloading after 261 and $325 \mathrm{~d}$ of conservation for farm 1 and farm 2 , respectively. On farm 1 , the BAB spores, mold, and $\mathrm{pH}$ were greater $(P<0.001, P<0.001$, and $P=$ 0.001 , respectively) in the ST silage than in the $\mathrm{OB}$ and the CORE silages. The BAB spore concentration in the ST silage was greater than $5 \log _{10} \mathrm{MPN} / \mathrm{g}$, whereas $\mathrm{BAB}$ spores from the CORE and the OB silages were approximately $2 \log _{10} \mathrm{MPN} / \mathrm{g}$. The silage sealed with the ST film had the greatest $\mathrm{pH}$ (5.89) and the greatest mold count (5.07 $\left.\log _{10} \mathrm{cfu} / \mathrm{g}\right)$, but no differences were observed between silage in the CORE and silage sealed with the OB film. The $\mathrm{dT}_{\text {section-ambient }}$ was also greater $(P=0.027)$ in silage sealed with the ST film than in the CORE and the OB silages. On farm 2, significant differences between the silage sealed with the ST and

Table 2. Farm 2: Butyric acid bacteria (BAB) spores, molds, yeasts, pH, and nitrate at ensiling of herbages from the core and from the peripheral areas sealed with an oxygen barrier and standard polyethylene films

\begin{tabular}{|c|c|c|c|c|c|}
\hline Item & $\mathrm{CORE}^{1}$ & \multicolumn{2}{|c|}{ Plastic film ${ }^{2}$} & $\mathrm{SE}$ & $P$-value \\
\hline BAB spores, $\log _{10}$ most probable number/g & 3.01 & 3.02 & 2.98 & 0.165 & 0.995 \\
\hline Yeasts, $\log _{10} \mathrm{cfu} / \mathrm{g}$ & 6.36 & 6.28 & 6.26 & 0.038 & 0.543 \\
\hline $\mathrm{pH}$ & 5.89 & 5.89 & 5.91 & 0.010 & 0.629 \\
\hline Nitrate concentration, $\mathrm{mg} / \mathrm{kg}$ of fresh matter & 2,408 & 2,388 & 2,363 & 62.7 & 0.965 \\
\hline
\end{tabular}

${ }^{1} \mathrm{CORE}=$ silage in the core of the bunker.

${ }^{2} \mathrm{OB}=$ silage under the oxygen barrier film; $\mathrm{ST}=$ silage under the polyethylene film. 
Table 3. Farm 1: Butyric acid bacteria (BAB) spores, molds, yeasts, pH, nitrate, and temperature difference between silage section and ambient temperature $\left(\mathrm{dT}_{\text {section-ambient }}\right)$ at unloading of silages after $261 \mathrm{~d}$ of conservation from the core and from the peripheral areas sealed with an oxygen barrier and standard polyethylene films

\begin{tabular}{|c|c|c|c|c|c|}
\hline Item & $\mathrm{CORE}^{1}$ & \multicolumn{2}{|c|}{ Plastic film ${ }^{2}$} & $\mathrm{SE}$ & $P$-value \\
\hline BAB spores, $\log _{10}$ most probable number/g & $2.09^{\mathrm{b}}$ & $2.24^{\mathrm{b}}$ & $5.04^{\mathrm{a}}$ & 0.363 & $<0.001$ \\
\hline Yeasts, $\log _{10} \mathrm{cfu} / \mathrm{g}$ & 3.05 & $<1.00$ & $<1.00$ & -3 & - \\
\hline $\mathrm{pH}$ & $3.60^{\mathrm{b}}$ & $3.99^{\mathrm{b}}$ & $5.89^{\mathrm{a}}$ & 0.280 & 0.001 \\
\hline Nitrate concentration, $\mathrm{mg} / \mathrm{kg}$ of fresh matter & $<30$ & $<30$ & $<30$ & - & - \\
\hline
\end{tabular}

${ }^{a, b}$ Means in the same row with different superscripts differ $(P<0.05)$.

${ }^{1} \mathrm{CORE}=$ silage in the core of the bunker.

${ }^{2} \mathrm{OB}=$ silage under the oxygen barrier film; $\mathrm{ST}=$ silage under the polyethylene film.

${ }^{3}$ Statistical analysis not performed.

OB films were found in $\mathrm{BAB}$ spore concentration $(P$ $<0.001)$, pH $(P=0.038)$, nitrate concentration $(P=$ $0.013)$, and $\mathrm{dT}_{\text {section-ambient }}(P=0.018)$. The ST silage had an average BAB spore concentration of $2.19 \log _{10}$ MPN/g, which was greater than the values of 1.19 and $1.29 \log _{10} \mathrm{MPN} / \mathrm{g}$ of the CORE and the OB silage, respectively. The greatest $\mathrm{pH}$ value was observed in the ST silage, with a value of 4.05 compared with 3.81 and 3.85 for the CORE and the OB silage, respectively. The ST silage also had the least nitrate concentration and the greatest $\mathrm{dT}_{\text {section-ambient }}$, whereas no differences were observed between the silage sealed with OB film and the CORE silage.

Tables 5 and 6 show the BAB spore concentrations, yeast and mold concentrations, $\mathrm{pH}$, nitrate concentration, $\mathrm{dT}_{\text {section-ambient, }}$ and number of hours with a temperature greater than $35^{\circ} \mathrm{C}$ of samples from the CORE and from the peripheral area of the silages after 6 and $15 \mathrm{~d}$ of air exposure. On farm 1, significant differences among the 3 treatments were observed for $\mathrm{BAB}$ spores $(P<0.001)$, molds $(P<0.001)$, and $\mathrm{pH}(P=0.022)$ after
$6 \mathrm{~d}$ of air exposure. The BAB spores were greater in the ST and OB silages than in the CORE silage. Mold counts of $5.85 \log _{10} \mathrm{cfu} / \mathrm{g}$ were observed in the OB silage, and this value was lower than those observed for the CORE and the ST silages. All silages were deteriorated greatly after $15 \mathrm{~d}$ of air exposure. Only mold counts were slightly lower in silage from the CORE than in silages from the peripheral areas.

On farm 2, significant differences between the ST and OB silages were observed for BAB spores $(P=0.008)$, mold counts $(P=0.020), \mathrm{pH}(P=0.004)$, nitrate concentration $(P=0.042), \mathrm{dT}_{\text {section-ambient }}(P=0.008)$, and hours with a temperature greater than $35^{\circ} \mathrm{C}$ during air exposure $(P=0.010)$ after $6 \mathrm{~d}$ of aerobic deterioration, whereas no differences were observed between the CORE and the OB silages. After 15 d of air exposure, significant differences were observed between the ST and $\mathrm{OB}$ silages in $\mathrm{BAB}$ spores $(P<0.001)$, nitrate concentration $(P=0.008), \mathrm{dT}_{\text {section-ambient }}(P=0.016)$, hours with a temperature greater than $35^{\circ} \mathrm{C}(P=0.002)$, and number of hours at which the nitrate concentration

Table 4. Farm 2: Butyric acid bacteria (BAB) spores, molds, yeasts, pH, nitrate, and temperature difference between silage section and ambient temperature $\left(\mathrm{dT}_{\text {section-ambient }}\right)$ at unloading of silages after $325 \mathrm{~d}$ of conservation from the core and from the peripheral areas sealed with an oxygen barrier and standard polyethylene films

\begin{tabular}{|c|c|c|c|c|c|}
\hline Item & $\mathrm{CORE}^{1}$ & \multicolumn{2}{|c|}{ Plastic film ${ }^{2}$} & $\mathrm{SE}$ & $P$-value \\
\hline BAB spores, $\log _{10}$ most probable number/g & $1.19^{\mathrm{b}}$ & $1.29^{\mathrm{b}}$ & $2.19^{\mathrm{a}}$ & 0.222 & $<0.001$ \\
\hline Yeasts, $\log _{10} \mathrm{cfu} / \mathrm{g}$ & 1.61 & $<1.00$ & 1.66 & -3 & - \\
\hline $\mathrm{pH}$ & $3.81^{\mathrm{b}}$ & $3.85^{\mathrm{b}}$ & $4.05^{\mathrm{a}}$ & 0.039 & 0.038 \\
\hline Nitrate concentration, $\mathrm{mg} / \mathrm{kg}$ of fresh matter & $2,250^{\mathrm{a}}$ & $2,025^{\mathrm{a}}$ & $1,688^{\mathrm{b}}$ & 98.5 & 0.013 \\
\hline
\end{tabular}

${ }^{a, b}$ Means in the same row with different superscripts differ $(P<0.05)$.

${ }^{1} \mathrm{CORE}=$ silage in the core of the bunker.

${ }^{2} \mathrm{OB}=$ silage under the oxygen barrier film; $\mathrm{ST}=$ silage under the polyethylene film.

${ }^{3}$ Statistical analysis not performed. 
Table 5. Farm 1: Butyric acid bacteria (BAB) spores, molds, yeasts, $\mathrm{pH}$, nitrate, average temperature difference between silage section and ambient temperature ( $\mathrm{dT}_{\text {section-ambient }}$ ) during air exposure, and number of hours with temperature over $35^{\circ} \mathrm{C}$ after 6 and $15 \mathrm{~d}$ of air exposure of samples from the core and from the peripheral areas sealed with an oxygen barrier (OB) and standard polyethylene (ST) films

\begin{tabular}{|c|c|c|c|c|c|c|c|c|c|c|}
\hline \multirow[b]{2}{*}{ Item } & \multicolumn{5}{|c|}{ Air exposure ${ }^{2}(6 \mathrm{~d})$} & \multicolumn{5}{|c|}{ Air exposure ${ }^{2}(15 \mathrm{~d})$} \\
\hline & $\mathrm{CORE}^{1}$ & OB & ST & $\mathrm{SE}$ & $P$-value & CORE & OB & ST & $\mathrm{SE}$ & $P$-value \\
\hline BAB spores, $\log _{10}$ most probable number/g & $3.20^{\mathrm{b}}$ & $5.64^{\mathrm{a}}$ & $6.00^{\mathrm{a}}$ & 0.306 & $<0.001$ & 5.12 & 6.35 & 6.79 & 0.338 & 0.084 \\
\hline Molds, $\log _{10} \mathrm{cfu} / \mathrm{g}$ & $7.54^{\mathrm{a}}$ & $5.85^{\mathrm{b}}$ & $7.75^{\mathrm{a}}$ & 0.253 & $<0.001$ & $7.16^{\mathrm{b}}$ & $8.63^{\mathrm{a}}$ & $8.49^{\mathrm{a}}$ & 0.224 & 0.001 \\
\hline Yeasts, $\log _{10} \mathrm{cfu} / \mathrm{g}$ & 1.96 & $<1.00$ & $<1.00$ & $-{ }^{2}$ & - & 6.71 & 6.77 & 5.52 & 0.223 & 0.051 \\
\hline $\mathrm{pH}$ & $6.79^{\mathrm{b}}$ & $6.69^{\mathrm{b}}$ & $7.30^{\mathrm{a}}$ & 0.142 & 0.022 & 6.85 & 6.77 & 7.49 & 0.169 & 0.211 \\
\hline Nitrate concentration, $\mathrm{mg} / \mathrm{kg}$ of fresh matter & $<30$ & $<30$ & $<30$ & - & - & $<30$ & $<30$ & $<30$ & - & - \\
\hline $\mathrm{dT}_{\text {section-ambient }},{ }^{\circ} \mathrm{C}$ & 14.9 & 18.3 & 21.2 & 2.32 & 0.587 & 13.8 & 13.5 & 16.2 & 2.26 & 0.868 \\
\hline Hours with $t>35^{\circ} \mathrm{C}$ & 32 & 72 & 80 & - & 0.322 & 148 & 261 & 296 & - & 0.117 \\
\hline
\end{tabular}

${ }^{\mathrm{a}, \mathrm{b}}$ Means in the same row for the same air exposure period with different superscripts are different $(P<0.05)$.

${ }^{1} \mathrm{CORE}=$ silage in the core of the bunker.

${ }^{2} \mathrm{OB}=$ silage under the oxygen barrier film; $\mathrm{ST}=$ silage under the polyethylene film.

${ }^{2}$ Statistical analysis not performed.

Table 6. Farm 2: Butyric acid bacteria (BAB) spores, molds, yeasts, $\mathrm{pH}$, nitrate, average temperature difference between silage section, and ambient temperature (dT $\mathrm{T}_{\text {section-ambient }}$ during air exposure, and number of hours with temperature greater than $35^{\circ} \mathrm{C}$ after 6 and $15 \mathrm{~d}$ of air exposure of samples from the core and from the peripheral areas sealed with an oxygen barrier and standard polyethylene films

\begin{tabular}{|c|c|c|c|c|c|c|c|c|c|c|}
\hline \multirow[b]{2}{*}{ Item } & \multicolumn{5}{|c|}{ Air exposure $^{2}(6 \mathrm{~d})$} & \multicolumn{5}{|c|}{$\operatorname{Air}_{\text {exposure }}^{2}(15 \mathrm{~d})$} \\
\hline & $\mathrm{CORE}^{1}$ & OB & $\mathrm{ST}$ & $\mathrm{SE}$ & $P$-value & CORE & OB & $\mathrm{ST}$ & SE & $P$-value \\
\hline BAB spores, $\log _{10}$ most probable number/g & $1.28^{\mathrm{b}}$ & $1.14^{\mathrm{b}}$ & $2.14^{\mathrm{a}}$ & 0.164 & 0.008 & $1.34^{\mathrm{b}}$ & $1.76^{\mathrm{b}}$ & $3.07^{\mathrm{a}}$ & 0.215 & $<0.001$ \\
\hline Molds, $\log _{10} \mathrm{cfu} / \mathrm{g}$ & $1.15^{\mathrm{b}}$ & $1.78^{\mathrm{b}}$ & $2.81^{\mathrm{a}}$ & 0.271 & 0.020 & 1.89 & 3.24 & 4.74 & 0.444 & 0.087 \\
\hline Yeasts, $\log _{10} \mathrm{cfu} / \mathrm{g}$ & $<1.00$ & $<1.00$ & 3.13 & -3 & - & 1.30 & 3.40 & 1.17 & 0.587 & 0.210 \\
\hline $\mathrm{pH}$ & $3.81^{\mathrm{b}}$ & $3.84^{\mathrm{b}}$ & $4.08^{\mathrm{a}}$ & 0.041 & 0.004 & $3.83^{\mathrm{b}}$ & $5.43^{\mathrm{ab}}$ & $6.71^{\mathrm{a}}$ & 0.411 & 0.014 \\
\hline Nitrate concentration, $\mathrm{mg} / \mathrm{kg}$ of fresh matter & $2205^{\mathrm{b}}$ & $2137^{\mathrm{b}}$ & $1519^{\mathrm{a}}$ & 133.2 & 0.032 & $2,160^{\mathrm{a}}$ & $2,057^{\mathrm{a}}$ & $1,052^{\mathrm{b}}$ & 181.2 & 0.008 \\
\hline $\mathrm{dT}_{\text {section-ambient, }}{ }^{\circ} \mathrm{C}$ & $-0.9^{b}$ & $1.6^{\mathrm{b}}$ & $9.9^{\mathrm{a}}$ & 1.60 & 0.008 & $0.3^{\mathrm{b}}$ & $2.8^{\mathrm{b}}$ & $13.6^{\mathrm{a}}$ & 2.126 & 0.016 \\
\hline Hours with $t>35^{\circ} \mathrm{C}$ & $0^{\mathrm{b}}$ & $0^{\mathrm{b}}$ & $57^{\mathrm{a}}$ & - & 0.010 & $0^{\mathrm{b}}$ & $6^{\mathrm{b}}$ & $179^{\mathrm{a}}$ & - & 0.002 \\
\hline Hours with $\mathrm{NO}_{3}<1,000 \mathrm{mg} / \mathrm{kg}$ of fresh matter & 0 & 0 & 0 & - & - & $0^{\mathrm{b}}$ & $0^{\mathrm{b}}$ & $54^{\mathrm{a}}$ & - & 0.037 \\
\hline
\end{tabular}

$\lesssim \quad{ }^{a, b}$ Means in the same row for the same air exposure period with different superscripts are different $(P<0.05)$.

${ }^{1} \mathrm{CORE}=$ silage in the core of the bunker.

$\underset{z}{2} \mathrm{OB}=$ silage under the oxygen barrier film; $\mathrm{ST}$ = silage under the polyethylene film.

${ }^{3}$ Statistical analysis not performed. 
was below $1,000 \mathrm{mg} / \mathrm{kg}$ of $\mathrm{FM}(P=0.037)$. The $\mathrm{BAB}$ spore concentration of $3.07 \log _{10} \mathrm{MPN} / \mathrm{g}$ observed in the ST silage was greater than the values of BAB spores of 1.34 and $1.76 \log _{10} \mathrm{MPN} / \mathrm{g}$ observed in the CORE and in the OB silage, respectively. The ST silage also had the greatest values for $\mathrm{pH}$ (6.71) and $\mathrm{dT}_{\text {section-ambient }}$ $\left(13.6^{\circ} \mathrm{C}\right)$, and the least value for nitrate concentration $(1,052 \mathrm{mg} / \mathrm{kg}$ of FM). Even after $15 \mathrm{~d}$ of air exposure, no differences were observed between the OB and CORE silages.

Figure 1 reports the $\mathrm{BAB}$ spore concentration data observed during the aerobic deterioration trials re- gressed on $\mathrm{pH}$, mold count, nitrate concentration, and $\mathrm{dT}_{\text {section-ambient }}$. The $\mathrm{pH}$, mold count, and $\mathrm{dT}_{\text {section-ambient }}$ showed a positive relationship with $\mathrm{BAB}$ spore concentrations, whereas nitrate concentration was negatively related. All equations had adjusted coefficients of determination greater than 0.70 and low root mean square errors.

\section{DISCUSSION}

In corn silage, BAB spores seem to be crucial in contaminating the rations and the bulk milk when
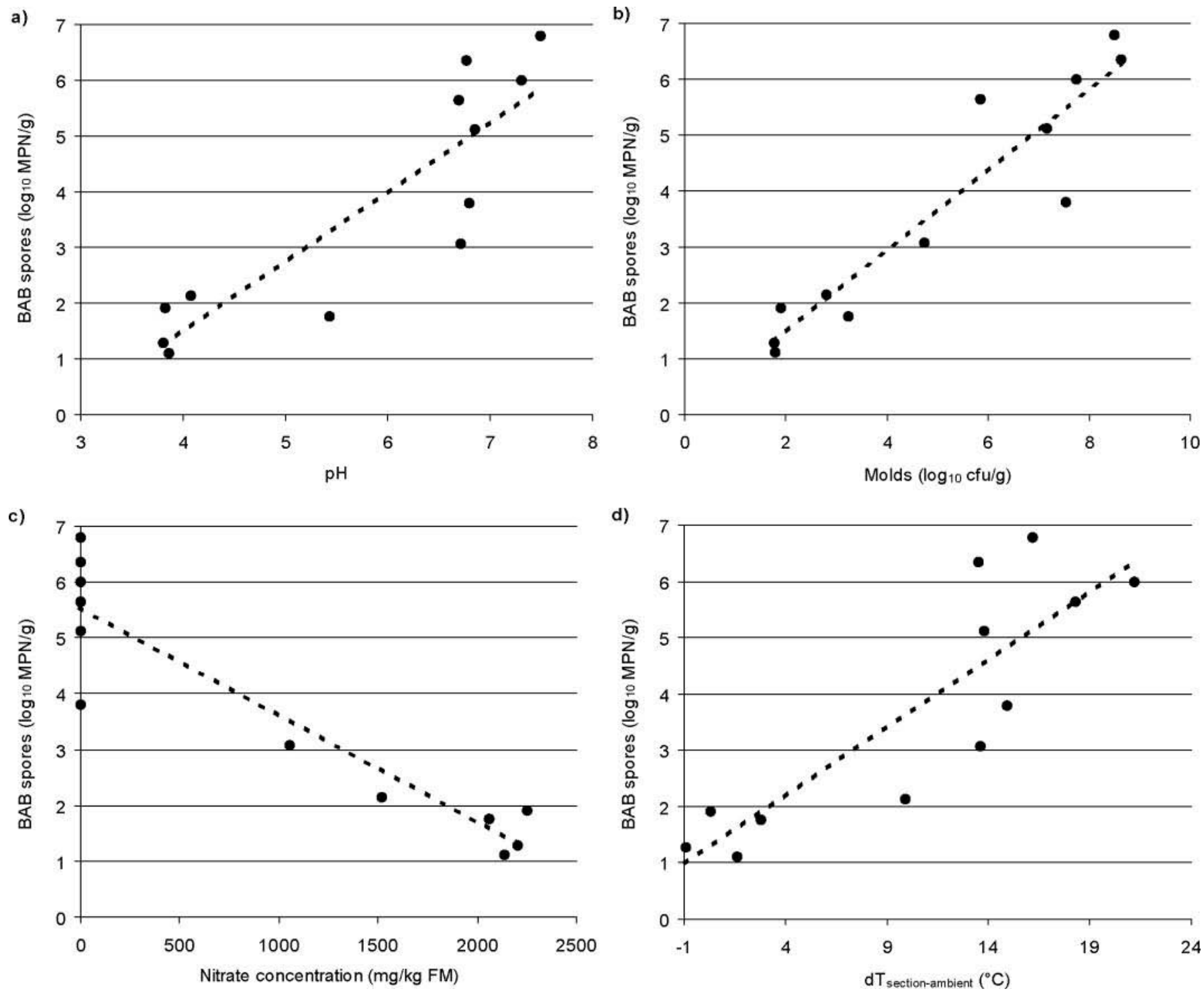

Figure 1. Aerobic deteriorated silages (pooled data of farms 1 and 2): butyric acid bacteria (BAB) spore concentrations in relation to $\mathrm{pH}$, mold count, nitrate concentration, and differences between silage temperature and ambient temperature ( $\left.\mathrm{dT}_{\text {section-ambient }}\right)$. Regressions obtained were a) BAB spores $\left[\log _{10}\right.$ most probable number $\left.(\mathrm{MPN}) / \mathrm{g}\right]=1.26 \mathrm{pH}-3.55\left[\mathrm{r}^{2}\right.$ adj. $=0.75$; root mean square error $\left.(\mathrm{RMSE})=1.06\right]$; b) BAB spores $\left(\log _{10} \mathrm{MPN} / \mathrm{g}\right)=0.727$ molds $+0.01\left(\mathrm{r}^{2}\right.$ adj. $\left.\left.=0.87 ; \mathrm{RMSE}=0.781\right) ; \mathrm{c}\right) \mathrm{BAB}$ spores $\left(\log _{10} \mathrm{MPN} / \mathrm{g}\right)=-0.0193 \mathrm{nitrate}+5.55\left(\mathrm{r}^{2}\right.$ adj. $=0.85 ; \operatorname{RMSE}=0.818) ;$ and d) BAB spores $\left(\log _{10} \mathrm{MPN} / \mathrm{g}\right)=0.244 \mathrm{dT}+1.21\left(\mathrm{r}^{2} \mathrm{adj} .=0.72 ; \operatorname{RMSE}=1.13\right)$. 
silage is subjected to aerobic deterioration (Vissers et al., 2007), because corn silage is not a good substrate for $\mathrm{BAB}$ outgrowth when a good anaerobic condition is achieved during storage. By conducting trials on commercial farms, the present study clarifies some questions recently raised by Vissers et al. (2007) regarding whether the limitation of oxygen penetration can prevent the outgrowth of $\mathrm{BAB}$ spores during conservation and feed-out. The present study investigated all the steps from corn silage harvesting to feed-out on farm and the following aerobic deterioration tests in laboratory conditions, through a method that permitted the outgrowth of $\mathrm{BAB}$ spores in the same silage material to be traced from the beginning to the end of the trial (Borreani et al., 2007). This limited the sampling variability that is typical of trials conducted on commercial farm silages.

The primary habitat of BAB spores is soil and decaying plant and animal products (Cato et al., 1986). The presence of $\mathrm{BAB}$ spores in agricultural soil varies to a great extent and depends on the degree of OM degradation. Data collected in the Po plain (Italy) showed a mean content of $3.20 \log _{10} \mathrm{MPN} / \mathrm{g}$ in soil that had not received any organic fertilization for more than $20 \mathrm{yr}$, a content of $4.20 \log _{10} \mathrm{MPN} / \mathrm{g}$ in the soil of dairy farms with a low livestock stocking rate, and a content of 4.85 $\log _{10} \mathrm{MPN} / \mathrm{g}$ in soil regularly fertilized with animal slurry and manure at a rate of more than $50 \mathrm{t}$ of $\mathrm{FM} /$ ha (Borreani et al., 2002). The BAB spore concentrations in slurries and manures ranged from 2.30 to 4.70 $\log _{10} \mathrm{MPN} / \mathrm{g}$, depending on the stocking conditions and animal contamination during production (Östling and Lindgren, 1991). Butyric acid bacteria spores do not belong to the epiphytic microflora of crops, because this anaerobic genus on green plants is generally lower than $2.00 \log _{10} \mathrm{MPN} / \mathrm{g}$ (Östling and Lindgren, 1991). Its presence in silage crops is generally due to soil and residual manure contamination during harvest. In our trial, the BAB spore concentrations of corn after chopping ranged from 2.48 to $3.02 \log _{10} \mathrm{MPN} / \mathrm{g}$, with few variations between treatments and farms. Lin et al. (1992) reported a BAB spore concentration of 1.97 $\log _{10} \mathrm{MPN} / \mathrm{g}$ in standing corn crops, and this increased to $2.88 \log _{10} \mathrm{MPN} / \mathrm{g}$ in preensiled forage after chopping. In preensiled grass and legumes, BAB spores were reported to be in the range of less than $1.70 \log _{10} \mathrm{MPN} / \mathrm{g}$ (Rammer et al., 1994) to $4.36 \log _{10}$ MPN/g (Davies et al., 1996). When strict anaerobic conditions were ensured during the storage of silage (i.e., in the core of the silo), the number of $\mathrm{BAB}$ spores decreased from 2.76 and 3.01 $\log _{10} \mathrm{MPN} / \mathrm{g}$ at ensiling to 2.09 and $1.19 \log _{10} \mathrm{MPN} / \mathrm{g}$ at unloading for farm 1 and farm 2 , respectively. The data observed from the CORE silage were consistent with those of Cotto (1983), who, in a survey of 1953 corn silages, found an average BAB spore concentration of $2.23 \log _{10} \mathrm{MPN} / \mathrm{g}$, and they were also in the range of values observed by Corrot (1986), who reported an average $\mathrm{BAB}$ spore concentration of 1.0 to $3.0 \log _{10} \mathrm{MPN} / \mathrm{g}$ in the core of 20 surveyed corn silages, which had a greater homogeneity than in the peripheral areas. The decrease in $\mathrm{BAB}$ spore concentration during the storage period was more evident in the silage of farm 2 , and this could be related to the high nitrate concentration of this silage at ensiling. Bester and Claassens (1970) showed the important role of nitrites in stimulating spore germination of Clostridium butyricum and $C$. tyrobutyricum. Ando (1980) reported that nitrites induced germination of Clostridium perfrigens spores by acting directly on a component of the spore cortex. The same author reported that sodium nitrite could block the outgrowth stage, cell division stage, or even both when added as a meat-curing agent. Spoelstra (1983) reported that nitrate, probably because of its reduced nitrite and nitric oxide products, prevented clostridial growth during the silage acidification phase.

The lower oxygen permeability of the OB film than the ST film reduced the detrimental effect of oxygen permeation during storage and feed-out, especially on farm 1. Significant differences in BAB spore concentrations between the silages sealed with the ST and OB films were observed at unloading. Vissers et al. (2007) suggested that the growth of $\mathrm{BAB}$ spores requires sufficient amounts of oxygen penetration into the silo, and this requires time. Gas permeation models showed that, during storage, oxygen can penetrate up to a depth of $0.2 \mathrm{~m}$ from the top of a silage sealed with polyethylene sheets (McGechan and Williams, 1994). As reported in Borreani et al. (2007), silages in the 2 bunker silos in this experiment were conserved for more than 8 mo before feed-out. Furthermore, the 2 silos were opened in midsummer, when temperatures are known to increase the oxygen permeability of the film used to cover the silo. In this context, the $180-\mu \mathrm{m}$-thick polyethylene ST film could not prevent permeation of oxygen in the peripheral area of the silo during the storage period, because its permeability was $990 \mathrm{~cm}^{3} / \mathrm{m}^{2}$ per $24 \mathrm{~h}$ at $23^{\circ} \mathrm{C}$ and, if the film was heated to $50^{\circ} \mathrm{C}$ by summer temperatures, it could increase to more than 3,000 $\mathrm{cm}^{3} / \mathrm{m}^{2}$ per $24 \mathrm{~h}$ (G. Borreani and E. Tabacco; personal communication). These values were 14 to 7.5 times greater than the oxygen permeability values of the 125- $\mu \mathrm{m}$-thick OB film, which were reported to be 70 and $400 \mathrm{~cm}^{3} / \mathrm{m}^{2}$ per $24 \mathrm{~h}$ at 23 and $50^{\circ} \mathrm{C}$, respectively (Borreani et al., 2007). Douglas and Rigby (1974) demonstrated that the low tension of oxygen stimulates a few spores of $C$. butyricum to outgrow and replicate, and this outgrowth is then followed by the germination of the other spores in the medium. They suggested that 
the few cells that are initially able to metabolize can produce reduced NAD, which reduces the oxygen tension to a noninhibitory level for the remaining spores. The results from farm 1 demonstrated that high concentrations of $\mathrm{BAB}$ spores can occur already during the storage period in peripheral areas (to a depth of $0.4 \mathrm{~m}$ from the top), especially when low amounts of oxygen can penetrate the silo through the ST polyethylene cover for several months. A high concentration of $\mathrm{BAB}$ spores in the peripheral areas sealed with the ST polyethylene film was associated with visible spoilage, high $\mathrm{pH}$ values $(>5.00)$, high mold counts (>5 log $\mathrm{cfu} / \mathrm{g})$, and a $\mathrm{dT}_{\text {section-ambient }}$ of $13.6^{\circ} \mathrm{C}$ with a silage temperature greater than $35^{\circ} \mathrm{C}$. Furthermore, by analyzing the fermentation profiles of the silages from farm 1 , as reported by Borreani et al. (2007), it is possible to state that silage with an average $\mathrm{BAB}$ spore concentration of $5 \log _{10} \mathrm{MPN} / \mathrm{g}$ (with values ranging from 4.1 to $8.2 \log _{10}$ MPN/g) contained a limited amount of butyric acid (less than $0.2 \% \mathrm{DM})$ and ammonia nitrogen (11\% total nitrogen). Similar results were reported by Lafrenière (2007), who found BAB spore concentrations greater than $4 \log _{10}$ MPN/g during feed-out of silage, with butyric acid below the detection level. When clostridial activity took place during the anaerobic phase of silage fermentation, similar BAB spore concentrations could be observed (Pahlow et al., 2003) but were associated with high concentrations of butyric acid $(>2.5 \% \mathrm{DM})$, acetic acid ( $>4 \% \mathrm{DM})$, and ammonia nitrogen $(>20 \%$ total nitrogen; McDonald et al., 1991). On farm 2, a significant difference in $\mathrm{BAB}$ spore concentrations between the silages sealed with the ST and OB films was observed at unloading, but to a lesser extent because of a nitrate concentration greater than $1,000 \mathrm{mg} / \mathrm{kg}$ of $\mathrm{FM}$, which prevented BAB spore formation during the conservation period.

To better understand the role of air on BAB outgrowth during silage aerobic deterioration, silage samples from the bags buried in the bunker silos of the 2 farms were deteriorated in laboratory trials until $d$ 15. This time period was chosen to represent the average age of a silage in the peripheral areas at risk of air exposure when a feed-out rate of 0.7 to $1.4 \mathrm{~m} /$ wk is adopted. This removal rate range was suggested from data from a survey on commercial farms in Italy, where feed-out rates of 0.5 to $1.5 \mathrm{~m} /$ wk were observed in more than $70 \%$ of the surveyed farms (Tabacco and Borreani, 2002). During feed-out, air can penetrate the peripheral areas of a silo to up to $4 \mathrm{~m}$ from the feed-out face (Parsons, 1991), especially when the sealing cover is not weighted down or is weighted only with tires. Silo face removal rates of 1.07 and $1.50 \mathrm{~m} / \mathrm{wk}$ were recommended by Pitt and Muck (1993) and by Vissers et al. (2007) for the United States and the Netherlands, respectively, to avoid extended aerobic spoilage of the silage.

Silages from the core and the peripheral areas of the farm 1 bunker had already resulted in deterioration after $6 \mathrm{~d}$ of air exposure. Furthermore, these silages had temperatures greater than $35^{\circ} \mathrm{C}$ for more than 70 h. Butyric acid bacteria spore concentrations greater than $5 \log _{10} \mathrm{MPN} / \mathrm{g}$ were associated with high $\mathrm{pH}$ values and mold counts, with no differences between the ST and the OB silages. This means that a silage with poor aerobic stability, such as that observed on farm 1 (Borreani et al., 2007), quickly undergoes spoilage and $\mathrm{BAB}$ outgrowth when exposed to air, with no effect attributable to the film that was used for sealing. The extent of mold development during air exposure greatly influenced the $\mathrm{BAB}$ spore concentration by reducing the inhibitory conditions of $\mathrm{BAB}$ outgrowth. This is particularly related to the increases in silage $\mathrm{pH}$ and temperature and to the decrease in nitrate concentration, as shown by the regression equations in Figure 1. Bester and Claassens (1970) reported a $\mathrm{pH}$ of approximately 5.5 and temperatures of 24 to $40^{\circ} \mathrm{C}$ as optimal conditions for BAB spore germination. Residual nitrate in silage seems to be a key factor in preventing $\mathrm{BAB}$ outgrowth during aerobic deterioration, because an increase in $\mathrm{BAB}$ spore concentration was not observed until the amount of nitrate decreased below $1,000 \mathrm{mg} / \mathrm{kg}$ of FM, as observed on farm 2 . After 15 d of air exposure, the nitrate concentrations in silage sealed with the ST film showed a high range of variation, from 90 to $2,250 \mathrm{mg} / \mathrm{kg}$ of FM. In silage samples in which the nitrate concentration fell below $1,000 \mathrm{mg} / \mathrm{kg}$ of FM after air exposure, the BAB spore concentrations reached $3.97 \log _{10} \mathrm{MPN} / \mathrm{g}$. The nitrate concentration of $1,000 \mathrm{mg} / \mathrm{kg}$ of FM was very close to the values reported by Spoelstra (1983) as being an inhibitory factor for clostridial growth during the anaerobic phase of grass silage fermentation.

\section{CONCLUSIONS}

The results obtained in this study indicate that the use of a film with an oxygen permeability lower than $100 \mathrm{~cm}^{3} / \mathrm{m}^{2}$ per $24 \mathrm{~h}$ can prevent the outgrowth of BAB spores during silage conservation. Furthermore, the key roles of nitrate and mold development were shown to have a great influence on $\mathrm{BAB}$ spore outgrowth. This new OB film could contribute to improving the microbiological quality of whole-corn silage by eliminating the small fractions of silage with high BAB spore concentrations, especially on farms under critical conditions or with inadequate amounts of silage removed daily. 


\section{ACKNOWLEDGMENTS}

The authors wish to thank Bartolomeo Forzano (Industria Plastica Monregalese S.p.A., Mondovì, Italy) for providing the coextruded barrier plastic films (Silostop) used in the experiment. We would also like to thank Serenella Piano (Dipartimento di Agronomia, Selvicoltura e Gestione del Territorio, University of Turin, Turin, Italy) for the chemical and microbiological analyses. Sergio Francia and Pierangelo Franco are gratefully acknowledged for having made their bunker silos available. This work was funded by the Regione Piemonte, Assessorato Qualità, Ambiente e Agricoltura, years 2005 to 2008 project "Influenza della zona di produzione e del tipo di gestione aziendale sulla qualità del Grana Padano D.O.P. piemontese.” The 2 authors contributed equally to the work described in this paper.

\section{REFERENCES}

Ando, Y. 1980. Mechanism of nitrite-induced germination of Clostridium perfringens spores. J. Appl. Bacteriol. 49:527-535.

Bester, B. H., and J. W. Claassens. 1970. A few observations on the spore germination of butyric acid bacteria. S. Afr. J. Dairy Technol. 2:19-29.

Borreani, G., E. Tabacco, and L. Cavallarin. 2007. A new oxygen barrier film reduces aerobic deterioration in farm scale corn silage. J. Dairy Sci. 90:4701-4706.

Borreani, G., E. Tabacco, and G. Colombari. 2002. Influenza del deterioramento aerobico degli insilati sulla qualità dei prodotti caseari (Influence of aerobic deterioration of silages on milk and cheese quality). Inf. Agrario 11:57-61.

Cato, E. P., W. L. George, and S. M. Finegold. 1986. Genus Clostridium. Prazmowski, 1880, 23AL. Pages 1141-1200 in Bergey's Manual of Systematic Bacteriology. Vol. 2. P. A. H. Sneath, N. S. Mair, E. Sharpe, and J. G. Holt, ed. Williams and Wilkins, Baltimore, MD.

Colombari, G., G. Borreani, and G. M. Crovetto. 1999. Comparison of Lucerne silage and ventilated hay in maize silage-based rations for dairy cows for the production of milk destined for Grana cheese. Grass Forage Sci. 54:184-194.

Colombari, G., G. Borreani, and G. M. Crovetto. 2001. Effect of ensiling alfalfa at low and high dry matter on production of milk used to make Grana cheese. J. Dairy Sci. 84:2494-2502.

Corrot, G. 1986. Répartition géographique de la contamination butyrique dans les silos. Rapport no. 86013. Istitut Technique de l'Elevage Bovin, Paris, France.

Cotto, G. 1983. Sur la zone de l'emmenthal, trop de spores butyriques dans l'ensilage. Elev. Bovin 130:32-36.

Davies, D. R., R. J. Merry, and E. L. Bakewell. 1996. The effect of timing of slurry application on the microflora of grass, and changes occurring during silage fermentation. Grass Forage Sci. $51: 42-51$.

Douglas, F., and G. J. Rigby. 1974. The effect of oxygen on the germination and outgrowth of Clostridium butyricum spores and changes in the oxidation-reduction potential of cultures. J. Appl. Bact. 37:251-259.

Jonsson, A. 1989. The role of yeasts and clostridia in silage deterioration. PhD Diss. Report 42. Swed. Univ. Agric. Sci., Uppsala, Sweden.
Jonsson, A. 1991. Growth of Clostridium tyrobutyricum during fermentation and aerobic deterioration of grass silage. J. Sci. Food Agric. 54:557-568.

Klijn, N., F. F. J. Nieuwenhof, J. D. Hoolwerf, C. B. van der Waals, and A. H. Weerkamp. 1995. Identification of Clostridium tyrobutyricum as the causative agent of late blowing in cheese by species-specific PCR amplification. Appl. Environ. Microbiol. 61:2919-2924.

Kwella, M., and F. Weissbach. 1991. Clostridial spore content of silages and influence of air contact. Pages 477-450 in Silage Conservation Towards 2000. G. Pahlow and H. Honig, ed. Inst. Grassl. Forage Res. and Fed. Res. Ctr. Agric. BraunschweigVölkenrode, Braunschweig, Germany.

Lafrenière, C. 2007. Les ensilages butyriques-Pas dans mon silo. http://www.agrireseau.qc.ca/agriculturebiologique/documents/ Lafreniere_Carole.pdf Accessed on March 5, 2008.

Le Bourhis, A.-G., K. Saunier, J. Dore, J.-P. Carlier, J.-F. Chamba, M.R. Popoff, and J.-L. Tholozan. 2005. Development and validation of PCR primers to assess the diversity of Clostridium spp. in cheese by temporal temperature gradient gel electrophoresis. Appl. Environ. Microbiol. 71:29-38.

Lin, C., K. K. Bolsen, B. E. Brent, R. A. Hart, J. T. Dickerson, A. M. Feyerherm, and W. R. Aimutis. 1992. Epiphytic microflora on alfalfa and whole-plant corn. J. Dairy Sci. 75:2484-2493.

MacKown, C. T., and J. C. Weik. 2004. Comparison of laboratory and quick-test methods for forage nitrate. Crop Sci. 44:218-226.

McDonald, P., A. R. Henderson, and S. J. E. Heron. 1991. The Biochemistry of Silage. 2nd ed. Chalcombe Publications, Bucks, UK.

McGechan, M. B., and A. G. Williams. 1994. A model of air infiltration losses during silage storage. J. Agric. Eng. Res. 57:237-249.

Ohyama, Y., S. Masaki, and A. Takigawa. 1970. Studies on various factors affecting silage fermentation. VII. Effect of air introduction into a silo for a certain period after ensiling and the chemical quality of the silages. Jap. J. Zootech. Sci. 41:620-624.

Östling, C. E., and S. E. Lindgren. 1991. Bacteria in manure and on manured and NPK-fertilised silage crops. J. Sci. Food Agric. 55:579-588.

Pahlow, G., R. E. Muck, F. Driehuis, S. J. W. H. Oude Elferink, and S. F. Spoelstra. 2003. Microbiology of ensiling. Pages 31-93 in Silage Science and Technology. Vol. 42. D. R. Buxton, R. E. Muck, and J. H. Harrison, ed. Am. Soc. Agron., Crop Sci. Soc. Am., and Soil Sci. Soc. Am., Madison, WI.

Parsons, D. J. 1991. Modelling gas flow in a silage clamp after opening. J. Agric. Eng. Res. 50:209-218.

Pitt, R. E., and R. E. Muck. 1993. A diffusion model of aerobic deterioration at the exposed face of bunker silos. J. Agric Eng. Res. 55:11-26.

Rammer, C., C. Östling, P. Lingvall, and S. Lindgren. 1994. Ensiling of manured crops-Effects on fermentation. Grass Forage Sci. 49:343-351.

Spoelstra, S. F. 1983. Inhibition of clostridial growth by nitrate during the early phase of silage fermentation. J. Sci. Food Agric. $34: 145-152$.

Stadhousers, J., and S. F. Spoelstra. 1990. Prevention of the contamination of raw milk by making a good silage. Bull. Int. Dairy Fed. 251:24-31.

Tabacco, E., and G. Borreani. 2002. Extent of aerobic deterioration in farm maize silage as affected by silo management. Pages 178-179 in Proc. 13th Int. Silage Conf., Auchincruive, UK. L. M. Gechie and C. Thomas, ed. SAC, Auchincruive, UK.

Vissers, M. M. M., F. Driehuis, M. C. Te Giffel, P. De Jong, and J. M. G. Lankveld. 2006. Minimizing the level of butyric acid bacteria spores in farm tank milk. J. Dairy Sci. 90:3278-3285.

Vissers, M. M. M., F. Driehuis, M. C. Te Giffel, P. De Jong, and J. M. G. Lankveld. 2007. Concentrations of butyric acid bacteria spores in silage and relationships with aerobic deterioration. J. Dairy Sci. 90:928-936. 